\title{
Rethinking south-eastern Europe through a pan-European perspective
}

\section{Introduction}

To state the obvious, Europe today - and 'Europe' refers not only to western Europe, nor exclusively to the European Union - is completely different from what it was some fifteen years ago. So too is south-eastern Europe, although for different reasons. The break-up of the Socialist Federal Republic of Yugoslavia (SFRY) in the early 1990 s and, most of all, the 'transition through war' (transition guerrière) ${ }^{1}$ considerably affected the fate of the region.

In the first post-war decade, the European Union (EU) integration process, taken on a country-by-country basis, was the main incentive to reform. Regional initiatives, such as the South-east European Co-operation Initiative (SECI), the Stability Pact for South-Eastern Europe, launched in 1999 under the auspices of the OSCE, and the recently reframed Central European Free Trade Agreement (CEFTA) have received increased attention as the regional dimension - initially a somewhat neglected facet - is now seen as a crucial issue.

Thus, in this first phase, the EU can be said to have garnered the lion's share of attention to the detriment of pan-European organisations, such as the OSCE, the Council of Europe and UN agencies such as UNECE. This paper argues that, in the new geo-strategic environment, pan-European organisations must complement the EU approach. This contribution will, firstly, briefly review the current situation in southeastern Europe; secondly, outline a pan-European perspective; and, thirdly, briefly focus on the fate of regional initiatives.

\section{South-eastern Europe at a glance}

Main regional trends

The Stabilisation and Association Process (SAP) is the EU policy framework for the countries of the region - Albania, Bosnia and Herzegovina, Croatia, the former Yugoslav Republic of Macedonia, Serbia and Montenegro. ${ }^{2}$ At the EU Thessaloniki summit on 21 June 2003, the EU made the promise that south-east Europe countries could join the Union provided they bring themselves up to EU standards.

Where do we stand four years later? Slovenia - since May 2004 - Bulgaria and Romania - since January 2007 - are fully-fledged EU members. But the other countries remain knocking at the door: on the one hand, Croatia, the former Yugoslav Republic of Macedonia and Turkey as candidate countries; and, on the other, Albania, Bosnia and Herzegovina, Montenegro and Serbia as potential candidate countries. In-

1 See Marina Glamocak (2002) La Transition guerrière yougoslave Paris: L'Harmattan.

2 The main elements of this long-term commitment to the region were first presented in a Commission Communication (COM(99)235 of 26 May 1999). The Central European countries in transition, Bulgaria and Romania completed that process before joining the EU. 
deed, until the June 2007 EU summit (see below), the EU prospects of south-east Europe countries in 'post referendum Europe'3 appeared bleak: between 2005 and 2007, more than the speed and achievements of the reform process oriented on the EU acquis communautaires in the various countries of the region, it was the exceedingly long 'pause for reflection', the EU's limited 'absorption capacities'4 and 'enlargement fatigue' that were blocking the enlargement process. Nevertheless, all countries of the region are supposed to join the EU, sooner or later (see Table 1).

Table 1 - EU accession forecast for south-east Europe

\begin{tabular}{|l|c|c|c|c|}
\hline & SAA & Negotiations & EU & Euro \\
\hline Bulgaria & 1995 & 1999 & 2007 & 2009 \\
\hline Romania & 1995 & 1999 & 2007 & 2012 \\
\hline Croatia & 2005 & 2005 & 2010 & 2012 \\
\hline FYR Macedonia & 2005 & 2008 & $2012-2013$ & 2015 \\
\hline Albania & 2006 & 2009 & by 2015 & by 2017 \\
\hline Bosnia and Herzegovina & 2007 & 2009 & by 2015 & by 2017 \\
\hline Serbia & 2007 & 2009 & by 2015 & by 2017 \\
\hline Montenegro & 2007 & 2010 & by 2015 & 2002 \\
\hline
\end{tabular}

Source: Gligorov (2007).

Despite some back-pedalling, the situation of these countries shows - contrary to what is often stated - a far more positive than negative picture overall. This applies in a particular way to the economies of the region: their continued growth can be assessed to be sustainable (average GDP growth rates illustrate this: see Table 2) and the business climate has improved. The rapid growth of exports (even if not at the same speed as GDP), increased foreign investments and recovered labour markets also illustrate the improved economic environment. Other positive signs are the indicators of macroeconomic stability, low inflation, improved public sector performance and fiscal balance. Only employment tends to recover more slowly. Thus, the economies of south-east European countries clearly show signs of catching up. Of course, some crucial questions remain unresolved, including the status of Kosovo and Bosnia

3 Christophe Solioz (2007) (2005] 'The Balkans in Post-Referendum Europe' Turning Points in Post-War Bosnia Baden-Baden: Nomos, pp. 144-52.

4 To clarify this notion, recently converted to 'capacity to integrate,' see Siegfried Schultz and Ulrich Brasche (2007) 'Absorptionskapazität der Europäischen Union - eine Orientierungshilfe' Südosteuropa Mitteilungen 47(3): 6-19. 
and Herzegovina's problematic internal integration. Nonetheless, as noted by Vladimir Gligorov:

Stability and growth have proved to be much more resilient to political shocks and instabilities than in the past. ${ }^{5}$

Table 2 - Gross domestic product

\begin{tabular}{|c|c|c|c|c|c|c|c|c|c|c|c|c|}
\hline & 1995 & 2002 & 2003 & 2004 & 2005 & 2006 & 2006 & 2007 & 2006 & 2007 & \multirow{2}{*}{$\begin{array}{l}2006 \\
1990 \\
=100\end{array}$} & 2006 \\
\hline & & & & & & & \multicolumn{2}{|c|}{$1^{\text {st }}$ quarter } & \multicolumn{2}{|c|}{ forecast } & & 2000 \\
\hline Croatia & 6.8 & 5.6 & 5.3 & 4.3 & 4.3 & 4.8 & 6.0 & 7.0 & 5 & 5 & 113.4 & 132.4 \\
\hline FYR Macedonia & -1.1 & 0.9 & 2.8 & 4.1 & 3.8 & 3.1 & 2.2 & 7.0 & 4 & 4 & 100.6 & 110.3 \\
\hline Turkey & 7.2 & 7.9 & 5.8 & 8.9 & 7.4 & 6.1 & 6.7 & . & 5.5 & 6.5 & 186.1 & 131.0 \\
\hline $\begin{array}{l}\text { Candidate coun- } \\
\text { tries }\end{array}$ & 7.0 & 7.5 & 5.7 & 8.3 & 7.0 & 5.9 & 6.5 & . & 5.4 & 6.3 & 174.2 & 130.5 \\
\hline Albania & 8.9 & 4.3 & 5.8 & 6.2 & 5.6 & 4.9 & . & . & 5 & 5.5 & & 139.0 \\
\hline $\begin{array}{l}\text { Bosnia and Herze- } \\
\text { govina }\end{array}$ & 50.0 & 5.5 & 3.0 & 6.0 & 5.5 & 6.2 & . & . & 6 & 6 & . & 134.9 \\
\hline Montenegro & . & 1.7 & 2.4 & 4.2 & 4.0 & 6.5 & 6.8 & 6.6 & 5 & 5 & . & 119.9 \\
\hline Serbia & . & 4.2 & 2.5 & 8.4 & 6.2 & 5.7 & 7.0 & 8.7 & 5 & 5 & . & 136.4 \\
\hline $\begin{array}{l}\text { Potential candida- } \\
\text { te countries }\end{array}$ & . & 4.5 & 3.1 & 7.3 & 5.8 & 5.8 & . & . & 5.2 & 5.3 & . & 135.7 \\
\hline
\end{tabular}

Some figures preliminary. NB: real change in \% against preceding year Source: wiiw, July 2007.

\section{European integration process}

It is well-known that the enlargement process is also dependent on the EU's own internal reform process. After an excessively long 'pause for reflection', Angela Merkel - the German Chancellor who held the six-month rotating EU presidency during the first half of 2007 - intensified her diplomatic efforts in order to re-open the Union's treaty reform process. After Poland stepped back from a dramatic threat to veto any agreement, the breakthrough came on a Reform Treaty aimed at replacing the defunct proposed constitution. This Treaty will streamline EU decision-making, improve the EU's international presence with a High Representative and a permanent president and provide the institutional framework to resume the enlargement process. ${ }^{6}$

5 In Vladimir Gligorov and Sándor Richter et al. (2007) High Growth Continues, with Risks of Overheating on the Horizon (Vienna: wiiw; Research Reports No. 341, July), part B. 
This package should be finalised at an Intergovernmental Conference (IGC) to be organised in the summer of 2007; and it also includes an additional condition for candidate countries: a commitment to promote EU values. Further, there will be an obligation to notify the European Parliament and national parliaments of an application for membership. Thus, the Reform Treaty might include institutional changes increasing the entry difficulties for would-be EU members.

These already exist in the form of an unprecedented monitoring regime set up for Bulgaria and Romania. Indeed, when Bulgaria and Romania entered the EU on 1 January 2007, special provisions were made to facilitate and support smooth accession and, at the same time, to safeguard the proper functioning of EU policies and institutions. The European Commission monitors the application of law (the acquis communautaire) to ensure that these obligations are being met. Thus, the accession of both countries was accompanied by a set of specific accompanying measures put in place to prevent or remedy the remaining shortcomings that were identified in several areas. A special Co-operation and Verification Mechanism was established in the areas of judicial reform and the fight against corruption and organised crime which sets out benchmarks to provide a framework for monitoring progress in these areas. The European Commission approved the first reports on progress under the Co-operation and Verification Mechanism on 27 June 2007. ${ }^{7}$ Meanwhile, on 21 June 2007, the European Commission finalised its planning for the financial assistance that candidate and potential candidate countries will receive in 2007-2009 under the Instrument for PreAccession Assistance (IPA). ${ }^{8}$ Thus, the institutional and financial capacities to proceed with the integration process are now finally available.

6 The European Council agreed on 23 June 2007 to convene an IGC before the end of July 2007 which is tasked to draw up a Reform Treaty before the end of 2007 so as to allow for sufficient time to ratify the resulting treaty before the European Parliament elections in June 2009.

7 See Commission of the European Communities (2007) Report from the Commission to the European Parliament and the Council on Bulgaria's progress on accompanying measures following Accession (Brussels: $\operatorname{COM(2007)377,~} 27$ June 2007) and Report from the Commission to the European Parliament and the Council on Romania's progress on accompanying measures following Accession (Brussels: COM(2007)378, 27 June 2007). These reports have been prepared in this post-Accession perspective and seek to assess the progress made on the commitments made at the time of Accession. The reports are not monitoring reports; they are an assessment made under the Co-operation and Verification Mechanism established by Commission decision of 13 December 2006.

8 An overall indicative amount of $€ 3.96 \mathrm{bn}$ will help Croatia, the former Yugoslav Republic of Macedonia, Turkey, Albania, Bosnia and Herzegovina, Montenegro, Serbia and Kosovo (under UNSC Resolution 1244) enhance political and economic reform and development. It must be noticed that IPA Multi-Annual Indicative Planning Documents for 20072009 include under 'IPA Component II' significant means to enhance cross border co-operation. 
Table 3 - Transition indicators for 2006

\begin{tabular}{|l|c|c|c|c|c|c|c|}
\hline & $\begin{array}{c}\text { Large scale } \\
\text { privatisa- } \\
\text { tion }\end{array}$ & $\begin{array}{c}\text { Small } \\
\text { scale pri- } \\
\text { vatis- } \\
\text { ation }\end{array}$ & $\begin{array}{c}\text { Restruct- } \\
\text { uring }\end{array}$ & $\begin{array}{c}\text { Price } \\
\text { liberal- } \\
\text { isation }\end{array}$ & $\begin{array}{c}\text { Foreign } \\
\text { trade and } \\
\text { exchange } \\
\text { rate re- } \\
\text { gimes }\end{array}$ & $\begin{array}{c}\text { Compe- } \\
\text { tition poli- } \\
\text { cy }\end{array}$ & $\begin{array}{c}\text { Banking re- } \\
\text { form and } \\
\text { interest } \\
\text { rate liberal- } \\
\text { isation }\end{array}$ \\
\hline Albania & 3.00 & 4.00 & 2.33 & 4.33 & 4.33 & 2.00 & 2.67 \\
\hline B\&H & 2.67 & 3.00 & 2.00 & 4.00 & 3.67 & 1.67 & 2.67 \\
\hline Croatia & 3.33 & 4.33 & 3.00 & 4.00 & 4.33 & 2.33 & 4.00 \\
\hline Macedonia & 3.33 & 4.00 & 2.67 & 4.33 & 4.33 & 2.00 & 2.67 \\
\hline $\begin{array}{l}\text { Montene- } \\
\text { gro }\end{array}$ & 3.33 & 3.00 & 2.00 & 4.00 & 3.33 & 1.00 & 2.67 \\
\hline Serbia & 2.67 & 3.67 & 2.33 & 4.00 & 3.33 & 1.67 & 2.67 \\
\hline & $\begin{array}{c}\text { Stock ex- } \\
\text { change and } \\
\text { other non- } \\
\text { banking fi- } \\
\text { nancial } \\
\text { services }\end{array}$ & $\begin{array}{c}\text { Other in- } \\
\text { frastruc- } \\
\text { reform }\end{array}$ & Telecoms & Rail- & Electricity & Roads & Water and \\
sewage \\
\hline ways & & & & & & \\
\hline Albania & 1.67 & 2.00 & 3.00 & 2.00 & 2.67 & 2.00 & 1.67 \\
\hline B\&H & 1.67 & 2.33 & 2.33 & 3.00 & 3.00 & 2.00 & 2.00 \\
\hline Croatia & 3.00 & 3.00 & 3.67 & 2.67 & 3.00 & 3.00 & 3.33 \\
\hline Macedonia & 2.33 & 2.33 & 3.00 & 2.00 & 3.00 & 2.33 & 2.33 \\
\hline gro & 1.67 & 2.00 & 3.00 & 1.00 & 2.33 & 2.00 & 2.00 \\
\hline & 2.00 & 2.00 & 2.33 & 2.33 & 2.33 & 2.67 & 1.67 \\
\hline
\end{tabular}

NB: Progress is measured on a scale from 1 to 4 : with 4 and $4+(4.33)$ indicating that the level of development has been achieved. Source: Transition Report 2006.

Despite these recent positive changes, we have to consider some limits of the current integration process. 'Enlargement fatigue' has had negative consequences for the region while the 'pull factor' and stimulus for reform of the implementation processes, although not completely vanished, is less convincing today given their currently slow progress. In spite of the economies in the region now doing much better, 'reform fatigue' characterises the public governance and structural reforms of most of the countries - except Croatia - as illustrated by the indicators for the advance of transition published by the European Bank for Reconstruction and Development (see Table 3). Worse, aggressive nationalism has received a fresh impetus and is affecting the domestic divide in various countries. This might well affect stability and moves us into potentially dangerous and unpredictable territory. We may also observe that the 
'EU soft power' - conditionality built on attraction - worked pretty well in countries whose chances of accession were tangible and where the transformation process was already underway. But when it comes to political problems - as in Bosnia and Herzegovina, Serbia and UNMIK/Kosovo - the attraction of membership shows its limits. A more coercive approach based on conditionality but built on compulsion is obviously needed. This, of course, contradicts the trend toward more 'ownership'.

Local political forces - especially in Bosnia and Herzegovina, Serbia and UNMIK/Kosovo - are unable to agree about their own future but the limits of the technocratic and acquis-focused approach - successfully applied by the European Commission to the 2004 entrants, as well as to Romania and Bulgaria - are obvious. Given the politicised nature of the accession debate on Croatia and Turkey, and considering also the political and security issues presented by UNMIK/Kosovo, Serbia and Bosnia and Herzegovina, the EU needs to re-think the European project in the region and, above all, to embrace politics in order to make south-eastern Europe work. ${ }^{9}$ Indeed, it should be not forgotten that the EU enlargement project in the region is also very much a peace project. But the limits of the technical nature of the accession talks represent only one problem. The importance of regional co-operation - especially if we consider the magnitude of the economic dimension - is another central issue that must be addressed.

Affecting stability in the region as a whole and at the country level, in addition to economic prospects, are typical cross-border issues: foreign direct investment; trade and transport facilitation; people mobility and migration; environmental protection; and energy supply. These regional-trans-boundary issues must be addressed as part of a broader regional vision encompassing a geo-strategic role for these countries as bridging Europe and Asia, Europe and the middle east. Of course, this speaks in favour of a broader understanding of south-eastern Europe which links the Danube region and central and eastern Europe with western Asia and Russia. Against this background, regional initiatives, as well as pan-European regional organisations, should become more active in fostering the regional economic integration process within a pan-European framework. This would not interfere with, but would rather complement and reinforce, EU integration and the European Neighbourhood Policy (ENP). ${ }^{10}$ Among other elements of a pan-European approach with much added value is that these countries are deemed as 'European' under cultural, historic and geo-strategic considerations - emphasising that Europe is more than just an enlarged EU. This broader concept of Europe must now be made a reality.

\section{Perspectives on a pan-European approach}

\section{The necessity of a comprehensive framework}

Individual strategies and good-neighbourly relations cannot tackle all the challenges that the countries in the region face. National and bilateral solutions are not sufficient when it comes to economic development, climate change, migration pressure, energy

9 See T. K. Vogel (2006) 'Why the EU Needs to Embrace Politics if it Wants to Make the Balkans Work' in Denisa Kostovicova and Vesna Bojičić-Dželilović (eds.) Austrian Presidency of EU: Regional Approaches to the Balkans Vienna: Centre for the Study of Global Governance \& Centre for European Integration Strategies, pp. 62-70. 
policy strategies and international terrorism, etc. Only a pan-European vision, firstly, sets the bilateral issues and the regional dimension in a coherent and significant framework for an efficient development of economic, political and cultural co-operation; and, secondly, ensures a bold and new vision for south-eastern Europe and also for Europe as a whole.

Firstly, a truly pan-European approach systematically links national and regional, local and global perspectives in a multilateral co-operation framework - moving resolutely beyond national country-based strategies and bilateral country-to-country approaches. Secondly, it encompasses political and socio-economic aspects, the security dimension and the development challenges. Thirdly, it covers the whole of eastern and south-eastern Europe, the Caucasus region and Russia, reaching out towards eurasia, including the Caspian region and Central Asia.

Such an approach could contribute to overcoming the new divisions and contradictions induced by the latest round of the EU enlargement. ${ }^{11}$ Indeed, today more than in the past, south-eastern Europe and the Black Sea region are heterogeneous areas encompassing EU members, would-be members and countries explicitly barred from an EU accession perspective - such as Ukraine, Russia and the Caucasian states. The increased complexity of bilateral and regional relations is illustrated by the Romanian and Bulgarian case: as new EU members, they must strengthen their borders with their eastern neighbours - but this contradicts and undermines the promotion of regional co-operation. Economic co-operation provides another example: the development of free trade areas are, as such, welcomed but they must take due account of EU member states and countries being bound to the EU's common commercial policy by a customs union and thus being unable autonomously to participate in regional free trade schemes. There is more: co-operation within the region and co-operation between the region and the EU on the one hand and, on the other, the co-existence of numerous co-operation programmes - such as the pre-accession process, the European

10 The European Neighbourhood Policy (ENP) - an adapted strategy for a 'wider Europe' intends to prevent the emergence of new dividing lines on the European continent and to establish close partnership-based relations, focusing on strengthening security and stability, with non-EU member states. The ENP has an impressive and comprehensive regional coverage, targeting all European states of the Commonwealth of Independent States (CIS), including the south Caucasus and all the Mediterranean states of the Barcelona process. But the ENP does not represent an enlargement policy, nor does it aim to open up the prospect of membership to the countries concerned or to provide specific accession prospects - even if it does not prejudge the prospects for some countries that may, at some future point, apply for membership, which is strongly desired by Ukraine, Moldova, Georgia and Armenia. See Commission of the European Communities (2004) Communication from the Commission: European Neighbourhood Policy Strategy Paper (Brussels: $\operatorname{COM}(2004) 373,12$ May); and Commission of the European Communities (2006) Communication from the Commission: On Strengthening the European Neighbourhood Policy (Brussels: COM(2006)726, 4 December).

11 On 1 May 2004, the EU welcomed ten more member states: Cyprus; the Czech Republic; Estonia; Hungary; Latvia; Lithuania; Malta; Poland; Slovakia; and Slovenia. This was the fifth time that the EU accepted new members, bringing the total from 15 to 25 member states. On 1 January 2007, this latest round of enlargement came to its conclusion with the accession of two more countries: Bulgaria and Romania. 
Neighbourhood Policy, the strategic partnership with Russia and bilateral agreements and action plans - considerably augment the structural complexity and tension that must be strategically addressed.

An additional divide must also be taken into account - the division between an economically and political stable Europe and a Europe characterised by economic and political instability. Thus, there is a division between the economically-developed Europe - 'old Europe', with some central European countries - and an under-developed Europe - most south-east European countries, Russia, the Caspian basin and central Asia. Looked at the other way round, the experience of 'new Europe' in the fields of innovation and economic restructuring may provide a starting point for overcoming the conventional policies of 'old Europe', where strong obstacles hamper privatisation and liberalisation. Such an approach suggests, firstly, that new ideas may come out of the 'other Europe' - notably in the field of social reform - and, secondly, that the transformation process is not over and not only in south-eastern Europe.

In practical terms, these divisions are reflected, for example, in the more difficult conditions for crossing the borders of the new EU members and the consequent problems for business. This fragmentation clearly undermines the potential for broad regional and pan-European co-operation, particularly in the economic realm. This affects south-eastern Europe but also the Black Sea region ${ }^{12}$ - an expanding market with an economic potential that remains largely untapped. We may also mention other typical regional issues: energy resources and energy security measures; and environmental protection. Countries from the region are too small to adopt individual strategies in the transport sector: so there are also the issues of the upgrading of transport infrastructures, trade development and facilitation.

Consequently, the reduction of administrative barriers to the free movement of goods, people, services and capital obviously requires a multilateral, inclusive framework. Of course, the above-mentioned lines of division benefit forces opposed to the stabilisation of the region and, therefore, ought to be countered by effective and appropriate policy - notably through conflict-resolution and confidence-building mechanisms addressing the political tensions and the frozen conflicts between states ${ }^{13}$ as well as shared measures against illegal migration, trafficking and organised crime. ${ }^{14}$

12 The Black Sea region includes Greece, Bulgaria, Romania and Moldova in the west, Ukraine and Russia in the north, Georgia, Armenia and Azerbaijan in the east and Turkey in the south. Armenia, Azerbaijan, Moldova and Greece are not littoral states, but history, proximity and close ties make them natural regional actors. Black Sea Economic Co-operation (BSEC), established in 1992, is a relevant organisation with a wide membership including the above-listed Black Sea countries plus Albania, Russia, Serbia and Turkey as founding member states. Seven EU member states have observer status. See the EU's updated Black Sea policy in: Communication from the Commission to the Council and the European Parliament: Black Sea Synergy - New Regional Co-operation Initiative (Brussels: $\operatorname{COM}(2007) 160,11$ April 2007).

13 More than south-eastern Europe, the Black Sea region is concerned with 'frozen' conflicts (Transnistria, Abkhazia, South Ossetia and Nagorno-Karabakh).

14 The București-based SECI Regional Centre for Combating Trans-border Crime has developed best practice in this field. 
In our view, only a pan-European framework can address and overcome these divisions.

A re-invigorated pan-European approach would, firstly, foster the European identity of these countries; secondly, contribute to the development of a common EU-USRussian approach to the open questions; and, thirdly, promote a pan-European economic integration and co-operation process beyond too narrowly conceived regional frameworks. Within a renewed pan-European and transatlantic dynamic, eastern and south-eastern European countries have a major role to play - being more open to cooperation with the US, Russia and non-EU eastern European countries in the Black Sea region and the Caucasus. The three above-mentioned dimensions correspond exactly to the priorities of the pan-European institutions. Consequently, complementing the EU integration process, pan-European organisations - by definition inclusive ${ }^{15}-$ should give life to a renewed pan-European dynamic.

\section{South-eastern Europe's key challenge}

There are obviously needs specific to south-east European countries. Several regional initiatives contribute to shape regional co-operation (see next section) and the new multilateral Central European Free Trade Agreement (CEFTA) ${ }^{16}$ addresses the issue of regional trade, but hard security issues must still be tackled: the status of UNMIK/ Kosovo; and Bosnia and Herzegovina's internal integration. It is time to acknowledge that the conflicts in the region have common historical roots which warrants their being examined comprehensively, taking account of their inter-connectedness and the mutual influences. It is also high time that the belated state-building process is addressed given that it has considerably slowed the integration process, producing the irony that:

In the Balkans as a whole, today (...) there are more democracies than sovereign states,

15 Compared to the exclusive ones like the EU and NATO.

16 As of 1 May 2007, eight parties were the prospective members of the new CEFTA - Albania; Bosnia and Herzegovina; Croatia; Moldova; Montenegro; Serbia; the former Yugoslav Republic of Macedonia; and UNMIK/Kosovo under UN administration - which had negotiated the revision of the old CEFTA agreement together with Bulgaria and Romania. The new CEFTA (CEFTA 2006) officially entered into force on 26 July 2007 for the five parties which had ratified the agreement: Albania; Moldova; Montenegro; the former Yugoslav Republic of Macedonia; and UNMIK/Kosovo. These are not countries belonging to central Europe but to south-eastern Europe. The original CEFTA agreement was signed by the Visegrád Group (Poland, Hungary and the Czech and Slovak republics) in December 1992 and entered into force in July 1994; the participating countries wanted to enhance co-operation and facilitate European integration. Meanwhile, all the former participating countries have become EU members so, in fact, CEFTA has served as preparation for full EU membership. It has to be noted that, at the time of writing, the new CEFTA agreement has not yet been ratified by Croatia, Serbia and Bosnia and Herzegovina. 
as Ivan Krastev put it. ${ }^{17}$ Indeed, we may consider most of these countries as weak states - weak in terms of legitimacy, authority and institutionalisation, and especially in terms of the rule of law.

State-building demands a process of change, a politics of reform based on developments in society and in markets. If truth be told:

When it comes to the use of resources by the state, the stress is on targets and efficiency and not so much on their level. Indeed, weak states, being captured states too, often allocate and distribute a lot of resources which does not contribute to their capacity to lead in the reform and development effort. ${ }^{18}$

Thus, if states have a role to play as central policy-making institutions, reforms should be the consequence of developments in society and in markets. Of course, a well-organised state and consolidated democracy alone cannot secure reforms; other factors beyond the above-mentioned one also contribute to a favourable environment, regional stability and to co-operation matters. Therefore, for the region and for the sake of Europe as a whole, careful, long-term strategic thinking is called for here.

But the nation-building issue should also be addressed - the time has come to close still-open wounds, to secure long-lasting stability, to consolidate democracy and to ensure significant economic growth and prosperity. In order to move beyond the cliché that:

The international community has failed to offer a convincing perspective to the societies in the region, ${ }^{19}$

and to foster an agreement based on permanent solutions providing a solid political future to south-east European countries, an international conference on the future of the region - an initiative suggested by Milan Kučan - should be organised during 2008. ${ }^{20}$ This conference must be pan-European, in order to engage both the US and Russia as partners in this effort.

17 Ivan Krastev (2002) 'The Balkans: Democracy Without Choices' Journal of Democracy 13(93): 39.

18 Ivo Bićanić and Vladimir Gligorov, Ivan Krastev (2003) State, Public Goods and Reform Vienna: wiiw, p. 31.

19 International Commission on the Balkans (2005) The Balkans in Europe's Future Sofia, p. 7.

20 See Milan Kučan (2007) 'A New View for the Balkans' in Hannes Swoboda and Christophe Solioz (eds.) Conflict and Renewal: Europe Transformed. Essays in Honour of Wolfgang Petritsch Baden-Baden: Nomos, pp. 217-23. 


\section{The fate of regional initiatives in south-east Europe}

Regional initiatives in south-eastern Europe are often related to post-war situations. We might briefly recall the leading role of Yugoslavia in the Non-Aligned Movement (NAM), ${ }^{21}$ an international movement that has since lost most of its credibility. The end of the Cold War brought the 1988 Summit of Foreign Ministers of South-Eastern Europe (SFMSEE), a regional initiative renamed in 1996 the SouthEast European Co-operation Process (SEECP); and, in 1989, the Central European Initiative (CEI) - an initiative establishing a platform for mutual political, economic, scientific and cultural co-operation with a secretariat in Trieste $22-$ and the Black Sea Economic Co-operation (BSEC), a multilateral political and economic initiative based since 1994 in Istanbul. ${ }^{23}$ In 1995, after the Bosnian war, the European Council initiated the Royaumont Process to promote stability and good neighbourliness in south-eastern Europe, while the US initiated the South-East European Co-operation Initiative (SECI) in December 1996 to encourage co-operation among the countries of the region in order to facilitate south-east Europe's EU integration. ${ }^{24}$ The Kosovo crisis and NATO intervention in 1999 led to the establishment on 10 June 1999 of the Stability Pact for South-Eastern Europe. The Stability Pact's ambition was to replace the previous reactive crisis-intervention policy in the region with a comprehensive, long-term conflict-prevention strategy and to strengthen south-east Europe countries,

21 The concept of 'non-alignment' was coined by Indian Prime Minister Nehru in 1954 and the first summit was held in Belgrade in 1961. The world's 'non-aligned' nations declared their desire not to become involved in the east-west ideological confrontation of the Cold War. The movement lost credibility in the late 1960s when it was seen by critics to have become dominated by states allied to the Soviet Union. The movement fractured from its own internal contradictions when the Soviet Union invaded Afghanistan in 1979. PostYugoslav republics have expressed little interest in the NAM since the country's breakup. Malta and Cyprus ceased to be members when they joined the EU. The most recent summit of the Non-Aligned Movement took place in Havana in 2006. Information is available at http://www.cubanoal.cu/ingles/index.html.

22 The origin of the CEI lies in the agreement signed in Budapest on 11 November 1989 by Italy, Austria, Hungary and Yugoslavia, establishing a platform for co-operation called the Quadragonal Co-operation. In 1990, with the admission of Czechoslovakia, it became the Pentagonal Initiative and, in 1991, following the accession of Poland, it was renamed the Hexagonal Initiative. Following the dissolution of former Yugoslavia, the Vienna Summit in 1992 admitted the Republics of Bosnia and Herzegovina, Croatia and Slovenia, and approved the renaming of the grouping as the Central European Initiative. Macedonia was admitted in 1993 at the Budapest Summit. In 1993, the Secretariat started operating at the EBRD in London. Information is available at http://www.ceinet.org.

23 BSEC member countries are: Albania; Armenia; Azerbaijan; Bulgaria; Georgia; Greece; Moldova; Romania; Russia; Serbia; Turkey; and Ukraine. Seven EU countries, Croatia, Belarus, Egypt, Israel, Tunisia and the US are observers. Information is available at http:/ /www.bsec-organization.org.

24 SECI was launched as an idea in Vienna in 1995; the aim is to focus, instead of political co-operation, on effective operational issues. The SECI Participating States include: Albania; Bosnia and Herzegovina; Bulgaria; Croatia; Greece; Hungary; Moldova; Romania; Slovenia; the former Yugoslav Republic of Macedonia; Turkey; and, as of December 2000, the Federal Republic of Yugoslavia. Information is available at http://www.secinet.org. 
In their efforts to foster peace, democracy, respect for human rights and economic prosperity in order to achieve stability in the whole region..$^{25}$

The above list of initiatives, far from being complete, represents only the most prominent forums. There are obvious common features of these regional initiatives: the lists of objectives and membership generally overlap; ${ }^{26}$ their respective activities consist mostly of meetings; the budgets are small and cover infrastructure costs; there is a limited number of implemented projects; and overall output is modest. Exceptions are SECI, which focuses on a set of priorities - notably on cross-border projects in the areas of infrastructure development, trade and transport issues, security, energy, environment and private sector development - and the Stability Pact. The latter, often seen as just an additional forum for the exchange of views, has managed successfully to co-ordinate programmes and projects targeting a broad spectrum of initiatives focusing on energy and regional infrastructures, trade and investment, cross-border cooperation, parliamentary co-operation and the fighting of corruption and organised crime. It is noteworthy that SEECP is the only original form of co-operation among the countries in the region launched on their own initiative. ${ }^{27}$ Thus, except SEECP, the very notion of regional co-operation was part of the post-conflict stabilisation efforts of the international community and not a genuinely endogenous process.

Against this background, the ongoing process transforming the Stability Pact into the Regional Co-operation Council (RCC) indicates a major evolution towards more regional ownership ${ }^{28}$ Until recently, south-east European countries resisted most regional initiatives because they were seen as being too close to the Yugoslav model. Even if it was always obvious that these countries are also inextricably bound to eastern European countries by historical, cultural, political, social and economic ties, regional co-operation was often perceived and conducted only because it was a requirement from outside - an EU conditionality. Thus, 'regional co-operation' rhetoric was often just:

Another sign of dependency - because it [was] not owned or promoted primarily by the region itself. ${ }^{29}$

25 SCSP constituent document, Cologne 10 June 1999; available at: http://www.stabilitypact.org/constituent/990610-cologne.asp.

26 A typical list includes: strengthening of security and political co-operation; intensification of economic relations and co-operation in human resources; democracy; justice; combating organised crime; and, last but not least, facilitating approach to European and Euro-Atlantic structures.

27 SEECP Participating States are, as founding countries: Albania; Bulgaria; Greece; FYROM; Romania; Serbia and Montenegro; and Turkey. Bosnia and Herzegovina joined in February 2001 and Croatia in 2004. The Republic of Moldova has applied for observer status.

28 The Stability Pact will be phased out in February 2008 and replaced by the RCC, the headquarters of which will be based in Sarajevo. The first Secretary-General of the new organisation will be the Croat diplomat Hido Biščević. All countries of the region, regardless of their status vis-à-vis the EU or NATO, will be members of the RCC and its Board: Albania; Bosnia and Herzegovina; Bulgaria; Croatia; Greece; Macedonia (FYROM); Moldova; Montenegro; Romania; Serbia; Turkey; and UNMIK/Kosovo. 
But now the time is ripe for this major shift: south-eastern Europe seems much more open today to facing problems that can only be addressed on a regional basis. This includes attracting foreign investment, facing the energy supply issue and fighting organised crime. Business people routinely cross borders and realise strategic partnerships; cultural productions from varied parts of the region find audiences throughout the region; and artists and producers co-operate as if the wall of the recent past was never there. This applies in a particular way to the former Yugoslavia - the anti-Yugoslav fixation appears to be more and more outdated. At work here are forces linked to cultural proximity and affinity, as observed by Tihomir Loza:

Yugoslavia was more than a state. Once it ceased to exist and as the causes of conflict among its constituent parts fade, things that the people of the region want to share irrespective of political arrangements among them become prominent. ${ }^{30}$

Loza suggests this might be facilitated:

Because none of the ways in which Yugoslavia is really being recreated promises (...) that the region will again be shaped into a single country. ${ }^{31}$

Politicians are aware of this new mood. On 24 June 2007, Serbian President Boris Tadić apologised to Croats for war-related hardships: Croatian President Stjepan Mesić said it was especially significant as the former Serbian regime of Slobodan Milošević had caused the greatest losses to all [in the former Yugoslavia], including among Serbs. Zoran Milanović, leader of the main opposition Social Democratic Party, also praised Tadić's statement as evidence of a new leadership in Serbia. As highlighted by Ivo Sanader, the Prime Minister of Croatia:

It has become evident that the time is ripe to adjust some features of this co-operation network and architecture, to refocus activities in order to enhance the regional ownership dimension, to increase efficiency in order to achieve Euro-Atlantic strategic goals. Hence the sub-title of this conference - From the Stability Pact for South-Eastern Europe to the Regional Cooperation Council: Enhancing the Voice of the Region. ${ }^{32}$

Previous regional initiatives need careful re-calibration and innovative thinking. Firstly, regional and pan-European organisations must enhance co-ordination among themselves, especially when it comes to initiatives implemented in the region: pragmatism and (cost) efficiency are the keywords. To put it the other way round, in order

29 Gregor W. Kössler (2007) 'Regional Co-operation in South-East Europe' in Hannes Swoboda and Christophe Solioz (eds.) Conflict and Renewal: Europe Transformed. Essays in Honour of Wolfgang Petritsch Baden-Baden: Nomos, p. 225.

30 Tihomir Loza (2007) 'Yugoslavia: Rising from the Ashes' Transitions Online 26 June; available at http://www.tol.cz.

31 ibid.

32 Ivo Sanader (2006) 'Croatia's European Role and Responsibility in South East Europe as SEECP Chair', opening address to the international conference: Regional Co-operation Challenges 2007/2008. From the Stability Pact for South-Eastern Europe to the Regional Co-operation Council: Enhancing the Voice of the Region Zagreb, 8 September 2006. 
to enhance its capacities the RCC might consider focusing on achievable goals and professional expertise, relying on and involving such existing pan-European institutions as the Council of Europe, the OSCE and UNECE. Secondly, south-east European countries must encompass the process of wider regional co-operation, including with non-EU countries in eastern Europe, notably Russia, and countries in the Caucasus, Central Asia and the Mediterranean basin. Such a broad regional network would be of interest at political, economic and cultural levels. This would provide pan-European organisations with the necessary legitimacy to be considered as key actors.

\section{Conclusion}

The EU integration process represents a particularly strong source of outside interference for south-east European countries. Different to what happened in the case of the integration of central European countries, the EU is directly involved in the institutional development and decision-making processes of the next group of potential EU member countries. In the best case, instead of ownership, we may speak of an ownership-friendly 'positive conditionality' - to use a term coined by Othon Anastakis and Dimitar Bechev. ${ }^{33}$ Against this background, the establishment of the Regional Co-operation Council is sending out a strong signal: south-east European countries are shifting from a passive policy-tracking to a pro-active policy-making approach. This locally-owned regional co-operation process should be supported and completed by a broader pan-European approach that would focus on practical results and prioritise well-defined sectoral activities enhancing regional economic development.

From this viewpoint, south-east European countries should not consider pan-European organisations as a 'waiting room' but as partners able, firstly, to provide technical assistance in the application of norms and standards that also correspond to the acquis communautaire; secondly, to help them view their economic problems and policies in a pan-European rather than a purely national framework; and, thirdly, to up-grade their regional co-operation to truly pan-European level. In a broader sense, the already-available pan-European instruments may contribute to overcoming the newly-established divisions - between EU member, would-be member and non-member - and to the fostering of consensus at pan-European level.

Considering the importance of the pan-European dimension, both at the economic and the geo-strategic levels, pan-European organisations should re-invigorate their approach and work out a roadmap, focusing on the key issues of regional co-operation, for pan-European policies that could be used as a long-term strategic framework.

33 Othon Anastasakis and Dimitar Bechev (2003) EU Conditionality in South East Europe: Bringing Commitment to the Process Oxford: St Antony's College, European Studies Centre, April, p. 3. 